\title{
DESTERCEIRIZAÇÃO E FLEXIBILIDADE: RETORNO À INTEGRAÇÃO VERTICAL E O IMPULSO À POLIVALÊNCIA.
} OUTSOURCING REVERSE AND FLEXIBILITY: RETURN TO VERTICAL
INTEGRATION AND THE DRIVE TO POLYVALENCE. DESIMPARTITION ET FLEXIBILITÉ: RETOUR A L'INTÉGRATION VERTICALE ET L'AVANCE DE LA POLYVALENCE.

DESTERCERIZACIÓN Y FLEXIBILIDAD: RETORNO A LA INTEGRACION VERTICAL Y EL IMPULSO A LA POLIVALENCIA.

Sabrina de Oliveira Moura Dias*

ID https://orcid.org/0000-0002-6302-9674

RESUMO: Esta pesquisa tem por objetivo analisar o processo de flexibilização da organização do trabalho a partir de mudanças na gestão dos efetivos, tais como a terceirização, a destercerização e a polivalência. A partir do estudo de caso de uma unidade de produção siderúrgica buscar-se-á compreender a forma como a desterceirização aliada à polivalência permite a expansão da flexibilização e a redução de parte das resistências dos trabalhadores ao acúmulo de funções. Esta pesquisa foi elaborada com base em entrevistas com trabalhadores e ex-trabalhadores da empresa e de suas prestadoras de serviços, e com sindicalistas e ex-sindicalistas do Sindicato dos Metalúrgicos. Foram utilizados ainda na elaboração do texto os boletins sindicais e ações ajuizadas na Justiça do Trabalho relativas à desterceirização e à prática da polivalência na empresa. A desterceirização e o retorno a uma gestão mais verticalizada dos efetivos se desenvolveu em sintonia com o aumento da polivalência, expandindo a flexibilidade e reduzindo os postos de trabalho.

Palavras-chave: Desterceirização; terceirização; polivalência; siderurgia; flexibilidade.

ABSTRACT: This research aims to analyze the process of

\footnotetext{
* Doutora em Sociologia e Antropologia; Professora Adjunta do Departamento Multidisciplinar da Universidade Federal Fluminense (UFF) e do Mestrado Profissional em Administração Pública (PROFIAP), Volta Redonda, RJ, Brasil; e-mail: sabrinamoura@id.uff.br
} 
flexibilization of work organization based on changes in personnel management such as outsourcing and outsourcing reverse processes, and polyvalence. From the case study of a steel production unit, we will seek to understand how outsourcing reverse process combined with polyvalence allows the expansion of flexibilization and the reduction of part of the workers' resistance against accumulation of functions. This research was based on interviews with enterprise's outsourced and direct workers, former employees, and with trade unionists and former union members of the Metalworkers' Union. Also used in the drafting of the text were union bulletins and lawsuits filed at the Labor Court regarding the outsourcing reverse process and the practice of polyvalence in the steel industry. The outsourcing reverse process and the return to a more vertical management of workforce has been developed along with the increase of polyvalence, expanding flexibility and reducing the number of jobs.

Keywords: outsourcing reverse; outsourcing; polyvalence; steelmaking; flexibility.

$\boldsymbol{R} \boldsymbol{E} \boldsymbol{S U} \boldsymbol{M} \boldsymbol{E}^{\prime}:$ L'objectif de cette recherche est d'analyser le processus de flexibilisation de l'organisation du travail à partir des changements de la gestion du personnel par des dispositifs comme la sous-traitance, la re-internalisation et la polyvalence. A travers l'étude de cas d'un site de production d'acier l'objectif est de comprendre comment la désimpartition combinée à la polyvalence permet le développment de la flexibilisation et la réduction de partie de la résistance des travailleurs à accummulation de fonctions. Cette recherche s'utilise des entretiens avec des travailleurs et anciens travailleurs de l'entreprise et de ses prestataires de services, ainsi que des entretiens avec des syndicalistes et d'anciens membres $d u$ syndicat des métallurgistes. Les bulletins syndicaux et les poursuite judiciaire devant le tribunal du travail concernant la re-internalisation et la pratique de la polyvalence dans l'entreprise ont également été utilisés dans la rédaction du texte. La desimpartition et le retour à une gestion plus verticale du personnel ont été développés parallèlement à l'augmentation de la polyvalence, à l'accroissement de la flexibilité et à la réduction du nombre d'emplois.

Mots-clés: desimpartition; sous-traitance; polyvalence; production d'acier; flexibilité.

RESUMEN: Esta investigación tiene por objetivo analizar el proceso de flexibilización de la organización del trabajo a partir de cambios en la gestión de los efectivos, tales como la tercerización, la destercerización y la polivalencia. A partir del estudio de caso de una 
unidad de producción siderúrgica se buscará comprender la forma como la destercerización aliada a la polivalencia permite la expansión de la flexibilización y la reducción de parte de las resistencias de los trabajadores a la acumulación de funciones. Esta investigación fue elaborada con base en entrevistas con trabajadores y ex trabajadores de la empresa y de sus prestadoras de servicios, y con sindicalistas y ex sindicalistas del Sindicato de los Metalúrgicos. Se utilizaron también en la elaboración del texto los boletines sindicales y acciones ajuizadas en la Justicia del Trabajo relativas a la destercerización ya la práctica de la polivalencia en la empresa. La destercerización laboral y el retorno a una gestión más verticalizada de los efectivos se desarrolló en sintonía con el aumento de la polivalencia, expandiendo la flexibilidad y reduciendo los puestos de trabajo.

Palabras clave: destercerización; tercerización; polivalencia; siderurgia; flexibilidad.

\section{INTRODUÇÃO ${ }^{\text {*** }}$}

Há certo consenso entre pesquisadores e analistas das relações de trabalho e de produção de que as décadas de 1970 e 1980 foram marcadas por uma ruptura central nas organizações, no processo de trabalho e nas relações de trabalho então vigentes. De acordo com o arcabouço teórico produzido pela Escola da Regulação Francesa ${ }^{2}$, neste período, estabeleceram-se mudanças profundas nas formas de organizar e produzir nas empresas. A partir de então, as empresas teriam "abandonado" progressivamente as técnicas e princípios do modelo fordista de produção e se engajaram cada vez mais nas técnicas e princípios do novo modelo de organização, mais flexível e desburocratizado.

Durante as décadas de 1970 e 1980 consagrou-se no mundo a ideia de que os ganhos de produtividade da produção automobilística japonesa estavam associados ao desenvolvimento de novas práticas e métodos de trabalho na indústria. Como traços centrais da nova forma de organizar a produção - que se tornou tendência desde as últimas décadas do século XX - estavam: a multiplicação do número de pequenas e médias empresas integradas horizontalmente, com

\footnotetext{
1** Agradeço à Coordenação de Aperfeiçoamento de Pessoal de Nível Superior (CAPES) pela concessão de bolsa de Pós-doutorado que tornou possível a realização de parte deste trabalho junto ao Programa de Pós-Graduação em Sociologia Universidade Federal Fluminense (PPGS / UFF). 2 Vertente teórica que busca explicar as mudanças nos padrões de produção e regulação capitalista, e cujos autores mais destacados são Robert Boyer, Alain Lipietz e Michel Aglietta.
} 
menor divisão hierárquica interna, a expansão das subcontratações, a implantação do Just in Time (JIT) e do Controle de Qualidade Total $(\mathrm{TQC})^{3}$ nas empresas, o estímulo ao trabalho em equipe e à autonomia e polivalência ${ }^{4}$ dos trabalhadores, e a estipulação de recompensas vinculadas ao desempenho (Coriat, 1994). Os ganhos de produtividade no novo sistema dependiam da redução do número de trabalhadores e da busca de uma "fábrica de pessoal mínimo" (Coriat, 1994; Castells, 1999). Transformações em direção à polivalência, à autonomação e à auto-ativação ${ }^{5}$ possibilitaram o enxugamento dos quadros das empresas e conduziram à intensificação do trabalho (Coriat, 1994, p. 78). Em contraposição à padronização, à produção em massa, à ultra especialização do trabalho, e à fábrica "gorda" que caracterizavam a produção fordista, a reestruturação produtiva lançava as bases para uma fábrica "enxuta" e para uma produção alcunhada "pós-fordista" ou "Toyotista", capaz de se adaptar às variações na demanda e no consumo.

A reestruturação produtiva envolve os processos de inovação tecnológica, de mudança na relação entre as empresas, de inovação nos métodos de organização da produção (just in time, kan-ban ${ }^{6} \mathrm{e}$ qualidade total), de introdução de novos métodos de organização do trabalho (trabalho em equipe e polivalência) e de inovações na gestão do trabalho (adoção de métodos "participativos" e de envolvimento do trabalhador com a empresa) (Krein, 2007). A organização em rede e a desconcentração da produção nas empresas se opunham ao modelo fordista canônico de integração vertical (Coriat, 1994, p. 121). O desenvolvimento e expansão da polivalência e da terceirização / desverticalização das empresas encontravam-se ligados à difusão das técnicas de organização da indústria automobilística japonesa, mais precisamente ao conjunto de "prescrições" de eficiência veiculado pelo paradigma Toyotista. Entre as técnicas do novo modelo, a polivalência ou multifuncionalidade ocupava um papel de destaque na

3 Sistema de controle de qualidade que abrange todo o processo produtivo. O TQC estimula a participação dos trabalhadores na melhoria da produção e na diminuição, ou extinção de defeitos e retrabalhos. 4 Estímulo ao desempenho de tarefas e atividades variadas pelo trabalhador, e ao acúmulo de conhecimentos e competências em diferentes funções do processo produtivo.

5 A autonomação consiste em um sistema que conduz à parada automática das máquinas quando há funcionamento defeituoso na produção. Juntamente com a desespecialização, a polivalência e a auto-ativação, ela permite a reintrodução da gestão de qualidade no processo produtivo, evitando desperdícios (Coriat, 1994).

6 O Kan-ban consiste na orientação da produção a partir das encomendas já realizadas (Coriat, 1994). 
organização dos trabalhadores. Através dela, tornou-se possível levar a cabo um enxugamento drástico dos quadros de funcionários e garantir às empresas os ganhos de produtividade derivados da possibilidade de produzir apenas as quantidades necessárias, no tempo necessário, contando com um número cada vez menor de trabalhadores.

Embora grande entusiasmo tenha marcado a adoção destas práticas pelas empresas mundo afora, parte destas mudanças foram incorporadas de maneira lenta, e até mesmo "tardia" em países da periferia do sistema capitalista. Por outro lado, as mudanças em direção ao conjunto "formular" de técnicas consideradas mais "flexíveis" interagiram com instituições, organizações e trajetórias de desenvolvimento nacional diversas, criando especificidades no funcionamento destes mecanismos de flexibilização (Castells, 1999).

Neste contexto, a terceirização das atividades emerge como forma de ampliar a flexibilidade na gestão dos efetivos das empresas. A terceirização do trabalho caracteriza-se grosso modo pela transferência de atividades, funções e setores produtivos de uma empresa dita "contratante" para uma empresa contratada ou prestadora de serviços. Com o intuito de concentrar esforços nas etapas consideradas essenciais à produção - o core business empresarial - a empresa contratante transfere para sua(s) contratada(s) a realização de serviços ou a produção de produtos considerados complementares ou periféricos. A eficiência do modelo terceirizante de organização da força de trabalho adviria da "especialização" das atividades na contratante e na sua rede de fornecedores e prestadores de serviços, ou ainda, do fato de que cada empresa se ocuparia das tarefas que melhor sabe realizar. Em meio à forte competição entre as empresas, a especialização criaria um ambiente propício aos saltos tecnológicos (Leiria, 1991)

A despeito da consagração da terceirização como corolário da eficiência produtiva, a sua reversão, não foi incomum no Brasil nos últimos $\operatorname{anos}^{7}$. No entanto, embora em princípio o processo de reintegração vertical pudesse estar hipoteticamente associado à expansão dos efetivos das empresas, nos casos analisados por Dias e Oliveira (2012) a desterceirização não fez mais do que aumentar os quadros

7 Para uma discussão sobre a desterceirização em grandes empresas públicas e privadas no Brasil ver Romão e Cardoso (2011), Dias e Oliveira (2012) e Santos e Garrocho (2013). 
próprios das empresas na mesma medida em que diminuía o número global de postos de trabalho. Este enxugamento só foi possível uma vez que a desterceirização combinou-se à utilização de novas tecnologias e/ou à reorganização dos quadros de trabalhadores dentro das empresas. Tendo em vista as mudanças na organização do trabalho ocasionadas por estas "normas" de flexibilidade, aliadas às matizes e temporalidades específicas com os quais estas "normas" se defrontam com contextos particulares nos quais se desenvolvem, propomos a análise de caso da unidade produtiva siderúrgica Usina Presidente Vargas (UPV) da Companhia Siderúrgica Nacional (CSN), e de seus processos de desterceirização e de ampliação da polivalência. $\mathrm{Na}$ $\mathrm{CSN}$, o impulso e a resistência à polivalência estavam em franca expansão nos anos 2000, ocorrendo muitas vezes concomitantemente ao processo de desterceirização. Estima-se que a sincronia e sinergia entre a desterceirização e a polivalência estejam associadas tanto às limitações estabelecidas pelas leis e regulamentações em relação à terceirização antes da vigência da lei $\mathrm{n}^{\mathrm{o}} 13.429 / 2017^{8}$ e, por outro lado, à busca das empresas em superar as resistências à reestruturação dos postos de trabalho.

Esta pesquisa foi elaborada com base em entrevistas com trabalhadores e ex-trabalhadores da CSN e de suas prestadoras de serviços, e com sindicalistas e ex-sindicalistas do Sindicato dos Metalúrgicos do Sul Fluminense (Sindmetal-SF) ${ }^{9}$. Foram utilizados ainda na elaboração do texto os boletins sindicais e acórdãos referentes a ações ajuizadas na Justiça do Trabalho relativas à prática da dester-

8 Esta é a primeira lei a regulamentar a terceirização no país. A lei foi sancionada no âmbito da Reforma Trabalhista do governo Temer, tendo como um de seus principais dispositivos a possibilidade de terceirização irrestrita das atividades, contrariando a orientação da súmula $n^{\circ} 331$ do Tribunal Superior do Trabalho (TST), que a limitava às atividades-meio, acessórias das empresas.

9 Foram realizadas 27 entrevistas com trabalhadores, sindicalistas e ex-funcionários diretos e terceirizados da CSN no período de 2009 a 2014, que versavam sobre a terceirização e a desterceirização na CSN. Três entrevistas foram realizadas em $2018 \mathrm{com}$ o intuito de aprofundar e atualizar algumas questões sobre a polivalência. Os excertos dos depoimentos transcritos neste texto são de oito trabalhadores e dois sindicalistas. Entre estes oito trabalhadores, dois tinham trabalhado nas empresas terceirizadas e haviam sido incorporados pela CSN com a desterceirização. Um dos trabalhadores entrevistados foi demitido quando do encerramento do contrato da siderúrgica com a terceirizada em que trabalhava, e não atuava mais na usina à época da entrevista. Os outros cinco trabalhadores eram funcionários do quadro da empresa ou aposentados à época da entrevista. Os trabalhadores tinham idades variadas, no entanto, os trabalhadores " $\mathrm{E}$ " e "N", ex-terceirizados, tinham até 35 anos e estavam na UPV há menos de 10 anos, enquanto os demais entrevistados possuíam mais de 45 anos de idade e mais de 10 anos de "casa" à época da entrevista. A consulta aos boletins sindicais se refere aos anos de 2004 a 2015. No site do Tribunal Regional do Trabalho (TRT 1), consultamos os acórdãos dos processos trabalhistas contra a siderúrgica. As buscas foram feitas a partir de palavras-chave como "polivalência", "desterceirização" e "dupla função". 
ceirização e da polivalência na empresa.

\section{Terceirização e flexibilidade na siderurgia}

Uma das questões que esteve na origem desta pesquisa era sobre a possibilidade de leitura da desterceirização como uma prática "fordista" ou "pós-fordista", ou ainda, se o processo representava uma variante da produção flexível ou se ele a negava. O mesmo questionamento foi feito por Romão e Cardoso (2011) em trabalho sobre a desterceirização na Petrobrás de título "Primeirização": um novo modelo pós-fordista de organização do trabalho na indústria brasileira? A pergunta não carece de propósito: o modelo japonês pressupunha um conjunto de práticas variadas que conduziriam à flexibilidade, entre elas, a terceirização, a polivalência dos trabalhadores, a utilização de máquinas flexíveis, entre outras. Embora um intenso esforço tenha sido feito por grande parte da literatura para associar a terceirização à flexibilidade, ao pressupor o foco na especialidade ou no saber-fazer específico, a subcontratação de efetivos muitas vezes acentuou, pelo menos em tese, a especialização das funções por empresa. O que foi o movimento de desintegração vertical senão o movimento de repassar às empresas as atividades periféricas as quais as empresas principais não podiam, ou não tinham interesse em desenvolver com efetivos próprios? Desta racionalidade, derivaram dois tipos de terceirização, que intensificaram a segmentação do mercado de trabalho: a terceirização de especialidade e a de capacidade (Chaillou, 1977), ou ainda, a flexibilidade funcional e a flexibilidade numérica (Harvey, 2011). A terceirização de capacidade, ou flexibilidade numérica, representa o desempenho de atividades pela contratada de menor conteúdo tecnológico e qualificação, e implica quase sempre em empregos desprotegidos e precários. A terceirização de especialização abrange atividades que exigem maior qualificação e know-how, e caracteriza-se por empregos com maior proteção e pela maior autonomia da empresa contratada. Enquanto o segundo tipo de terceirização se realizava de maneira regular antes mesmo da expansão da crença nas virtudes do modelo desintegrado/ desburocratizado - posto que inclui atividades as quais a empresa 
principal é incapaz de desempenhar ${ }^{10}$-, o primeiro é particularmente tributário do modelo de redes, uma vez que implica na expansão do repasse de atividades antes desenvolvidas internamente.

A ideia da necessidade da especialização como verticalização das atividades desempenhadas foi defendida do ponto de vista da eficiência, pois, ao especializar um serviço, obter-se-ia uma melhoria na sua execução, o que geraria uma economia de escala ${ }^{11}$. Em certa medida, parte dos tribunais do trabalho fazia coro à ideia de eficiência da terceirização reconhecendo e legitimando o recurso à prática desde que houvesse "especialização" do serviço, e que a empresa não tivesse como objeto social dos contratos a realização de uma gama variada de atividades ${ }^{12}$. A verticalização como sinônimo de eficiência apresenta similitude com o viés de racionalização fordista/ taylorista, embora aqui, a tônica não esteja na ultra especialização por função ou por atividade, mas na especialização por empresa. A segmentação das atividades agora não se limita aos postos de trabalho e funções, mas perpassa também estruturas jurídicas, burocráticas e hierárquicas diferenciadas. Desta forma, a ampliação da terceirização se ancorou tanto na especialização das atividades, bem como atingiu, de forma recorrente no Brasil, as atividades desqualificadas ou de menor conteúdo técnico ${ }^{13}$, reproduzindo em parte características associadas do paradigma fordista/taylorista.

Tendo em vista o panorama descrito acima, se a terceirização se construiu como sinônimo de flexibilidade, poderíamos depreender que com a desterceirização, um movimento inverso, de retorno à rigidez, à verticalização e à ampliação dos quadros diretos está sendo colocado em prática por grandes empresas? Em conjunto com a maioria

\footnotetext{
10 Seja por falta de pessoal qualificado ou de tecnologia.

11 Uma terceirizada poderia oferecer serviços de um mesmo funcionário a diferentes empresas, embora não raro, o que a terceirização para atividades permanentes gera é a ocupação de postos de trabalho nas empresas principais por trabalhadores terceirizados fixos ou semifixos.

12 A súmula $\mathrm{n}^{\circ} 331$ do Tribunal Superior do Trabalho (TST) - utilizada para homogeneizar as decisões das instâncias inferiores sobre a terceirização antes da existência de uma lei sobre o tema - trazia em seu texto o critério da especialização como condição de legalidade da terceirização. O texto estatuía que "Não forma vínculo de emprego com o tomador a contratação de serviços de vigilância (lei $n^{\circ} 7013$, de 20/06/83), de conservação e limpeza, bem como a de serviços especializados ligados à atividade meio do tomador, desde que inexistente a pessoalidade e a subordinação direta." (Grifo nosso)

13 A terceirização no Brasil caracteriza-se por abranger empregos situados em estratos sociais com salário médio inferior (DIEESE, 2017), ou seja, ela atinge sobretudo aqueles que se encontram em situação mais vulnerável.
} 
dos autores e pesquisadores consideramos que a terceirização trouxe para as empresas e negócios elementos de inquestionável flexibilização do trabalho e dos contratos. $\mathrm{O}$ enxugamento dos quadros diretos das empresas, a transformação dos custos fixos com o trabalho em custos variáveis e a plasticidade das fronteiras permitiram às firmas dispor de mão de obra subcontratada na medida de suas necessidades. Em alguns ramos industriais como a Siderurgia, e em empresas integradas verticalmente e que se expandiram no período auge do fordismo, a terceirização foi estratégia essencial de modernização e de desverticalização, em suma, de adaptação ao modelo flexível. Para Castells (1999) esta adaptação das antigas empresas era indispensável, haja vista a incapacidade das burocracias verticalmente integradas de competirem no cenário da Economia Informacional Global, caracterizada por inovações técnicas, organizacionais e tecnológicas.

As práticas de flexibilização da produção e de introdução de novos métodos, técnicas e tecnologias foi mais intensa no setor automobilístico, o que fez com que parte destas tendências fossem consagradas com os nomes das empresas onde nasceram ${ }^{14}$. A despeito da intensidade com que certas técnicas viralizaram na prática organizacional e administrativa de diferentes empresas, as peculiaridades de cada processo produtivo ensejam a criação de adaptações. Com parte considerável de sua estrutura material e de seu capital imobilizado em máquinas e equipamentos, em complexos produtivos de dimensões monumentais, e recorrendo a uma força de trabalho numerosa, a siderurgia integrada ${ }^{15}$ construída no país em sua maior parte entre os anos 1940 e $1960^{16}$ apresenta um arranjo que de imediato sugere grande rigidez. Diferentemente da indústria automobilística, as usinas siderúrgicas integradas marcam fisicamente de forma acentuada e permanente os territórios em que se implantam, seja por suas dimensões visíveis, sua materialidade, seja pelos danos menos visíveis que elas causam ao ambiente e à saúde.

Em contraste com a produção automobilística, de caráter

14 Como o Fordismo, o Toyotismo e o Volvismo.

15 A siderurgia integrada caracteriza plantas produtivas que realizam todas as etapas de transformação do minério em aço, incluindo as etapas de redução da matéria-prima, refino e laminação, e os equipamentos e áreas de Coqueria, Altos-Fornos, Aciarias e Laminadores.

16 As duas maiores usinas integradas do Brasil iniciaram suas atividades neste período: a CSN em 1946, e a Usiminas em 1962. 
descontínuo, a siderurgia é uma indústria de processo contínuo. Enquanto na primeira uma esteira dita o ritmo da maior parte das atividades, ao mesmo tempo em que os operários realizam uma variedade de atividades de montagem do produto, o setor siderúrgico é caracterizado pela centralidade das máquinas na produção e pela ausência de contato direto com o bem produzido (Piccinini et al., 2011). Em função do papel desempenhado pelas máquinas no processo produtivo siderúrgico, a maior parte dos efetivos da fábrica se divide entre trabalhadores que operam as máquinas e aqueles que se ocupam da continuidade do funcionamento das máquinas ${ }^{17}$ (Piccinini et al., 2011). A produção é contínua, sem interrupção e, portanto, os equipamentos têm papel substancial na perenidade deste tipo de processo. Nas indústrias de processo contínuo, não é incomum a existência de tempo ocioso ${ }^{18}$, o que permitia, há alguns anos atrás, tempos de cochilos, pausas e descanso entre os trabalhadores ${ }^{19}$. Desta forma, ao se falar em paradigma e/ou modelo, é preciso se levar em conta que, a despeito da homogeneidade pela qual são apresentadas uma série de premissas e práticas, alguns setores, por suas peculiaridades, não se conformam tão facilmente às inovações concebidas para a indústria automobilística, ou ainda, apresentam particularidades que permitem maior ou menor aplicação de técnicas flexíveis.

\section{Terceirização e desterceirização na CSN}

Parte substantiva da força de trabalho na Companhia Siderúrgica Nacional foi terceirizada durante os anos 1990 e 2000, época da ampliação de medidas flexibilizadoras encampadas por governos com propostas liberalizantes e desregulamentadoras (Cardoso, 2003). Os anos 1990 caracterizaram-se pelo cultivo de uma ideologia

17 A operação de máquinas tem como atividade principal a preparação e o controle das máquinas e equipamentos das instalações industriais. A manutenção de máquinas e equipamentos, por sua vez, se dedica primordialmente às atividades de conservação, reparo e planejamento das ações de manutenção nas máquinas e equipamentos. De acordo com os dados da Rais, no ano de 2017 os maiores grupos de trabalhadores na atividade siderúrgica de produção de aços planos eram os "Operadores de Máquinas a vapor" (Família CBO/2002 8621) e "Mecânicos de máquinas industriais" (Família CBO/2002 9113), com respectivamente $11 \%$ e $16 \%$ do total de trabalhadores do setor. Desde o início da série em 2003, estes dois grupos representam o maior percentual de trabalhadores na siderurgia de produção de aços planos (Fonte: Data Viva, url: http://dataviva.info/pt/).

18 Principalmente na operação de equipamentos.

19 Obviamente longe da vigilância das chefias. 
neoliberal que impulsionou a abertura comercial, as privatizações, e levou internamente à ampliação da concorrência ${ }^{20}$ (Cardoso, 2003; Pochmann, 2008). Neste cenário, no vocabulário gerencial a terceirização emergia como forma "natural" de lidar com a ampliação da concorrência, uma vez que ela permitia uma redução de custos com o trabalho ${ }^{21}$. Foi neste contexto que a CSN ampliou a terceirização de sua força de trabalho, primeiramente, contratando grande parte de seus efetivos via subsidiárias, controladas e empresas terceiras e, nos anos 2000, com o fim da sua subsidiária Fábrica de Estruturas Metálicas (FEM), essencialmente através de prestadoras de serviços. Nos anos 1990, a súmula n 331 de 1993 editada pelo Tribunal Superior do Trabalho garantiu a expansão da possibilidade de terceirização legal para as atividades consideradas periféricas ou acessórias às empresas (Biavaschi e Droppa, 2011).

No interior da usina, as atividades que passaram por processo mais intenso de terceirização nestas décadas foram as atividades de manutenção de equipamentos, montagem e manutenção de estruturas metálicas, embalagem de bobinas e manutenção de equipamentos. A subcontratação da maior parte destas atividades nos anos 1990 e 2000 apresenta as características de uma terceirização de capacidade, ou de uma flexibilidade numérica, pois estas atividades até então eram desenvolvidas pelos quadros diretos da empresa ${ }^{22}$. No

20 No período que vai dos anos 1980 a 2016 - que fez parte da experiência da maior parte dos entrevistados nesta pesquisa - o setor siderúrgico no Brasil teve um decréscimo acentuado de postos de trabalho, saltando de 159.276 em 1988 para 79.465 em 1996. Este período de reestruturação para a privatização de grandes empresas como a CSN e a Usiminas foi marcado também pela introdução de métodos de racionalização da gestão dos efetivos e do trabalho, como o SIGMA e a polivalência. Nos anos 2000 , a atividade siderúrgica teve uma recuperação (atingindo cerca de 132 mil empregos em 2011), embora nunca tenha alcançado o número de postos de trabalho de 1988. Chama a atenção a evolução rápida do número de efetivos terceirizados das empresas, que se elevou de 12.320 funcionários em 1996 para 63.672 em 2011. Nos anos 2000, o número de efetivos terceirizados das empresas cresceu vertiginosamente, reduzindo a proporção de trabalhadores diretos/ subcontratados, e mantendo-se em um patamar próximo ao dos efetivos diretos em alguns anos, embora nunca superior.

21 Para os críticos da terceirização, esta redução se fazia às custas da redução de salários, benefícios e direitos dos trabalhadores (Marcelino, 2013; Druck e Franco, 2007) e, para os entusiastas, era fruto da especialização e do aumento da produtividade. Para alguns autores, a terceirização que visava reduzir os custos com o trabalho por meio de cortes de direitos e benefícios caracterizaria a terceirização "tupiniquim" (Faria, 1994), "defensiva" (Pochmann, 2008), ou a má terceirização (Carelli, 2007), enquanto para outros autores, a precarização está na essência deste mecanismo de flexibilização (Marcelino, 2013). Poucos autores questionaram a real capacidade da terceirização em reduzir os custos, levando em conta não a pressuposição das vantagens, mas a forma com a qual a terceirização interage com os trabalhadores e suas qualificações, disposições, com os sindicatos e as instituições. Ainda que a terceirização nem sempre produza a economia de custos prometida, ela ainda tem um efeito potencialmente desarticulador das identidades coletivas e da organização sindical.

22 Parte da manutenção especializada em equipamentos específicos e com maior conteúdo tecno- 
caso das atividades de transporte dos pátios ferroviários internos, a terceirização separou as funções antes complementares e integradas de manobreiros e maquinistas ${ }^{23}$. A despeito de estas atividades terem um caráter estreitamente coordenado e interdependente, manobreiros tornaram-se funcionários de empresas terceirizadas, enquanto maquinistas permaneceram empregados diretos da siderúrgica.

Nas atividades de manutenção de equipamentos - que abrange um número maior de funcionários - o processo de terceirização também teve por característica a separação entre atividades interligadas e interdependentes. No entanto, neste caso, não ocorreu a terceirização completa dos quadros. Enquanto nos anos 1980 e 1990 grande parte da manutenção da siderúrgica era realizada por quadros próprios ou de sua subsidiária FEM, nos anos 2000 a manutenção passou quase que inteiramente à responsabilidade de subcontratadas. No entanto, a siderúrgica nunca se desincumbiu inteiramente das atividades de manutenção. No quadro da empresa principal foi mantido um reduzido contingente de trabalhadores cuja função era inspecionar os serviços terceirizados e elaborar as Ordens de Serviços (OSs) ou RSs (Requisições de Serviços) indicando as quantidades de materiais e recursos, bem como a forma de execução das tarefas pelos terceirizados. A organização das atividades de manutenção direta e terceirizada se refletia na separação entre planejamento e execução, ou entre trabalho intelectual e trabalho manual respectivamente. De maneira convergente, na manobra, apesar da existência de supervisores terceirizados nas áreas, as ordens que dispunham sobre a natureza e a dinâmica das atividades dos manobreiros emanavam frequentemente de funcionários diretos ${ }^{24}$.

As características do tipo de terceirização colocado em prática na siderúrgica reduziram os possíveis custos advindos da dester-

\footnotetext{
lógico caracterizavam tipos de terceirização de especialização dentro da empresa. Estas terceirizações de atividades com forte conteúdo técnico ofereciam um estatuto diferenciado ao trabalhador terceirizado, em contraste com a terceirização de atividades com baixa qualificação.

23 Os manobreiros, ou manobradores são funcionários responsáveis pelo controle do tráfego nos pátios ferroviários internos da empresa. As composições ferroviárias dentro da CSN fazem o deslocamento de insumos e materiais acabados e semiacabados. Os manobreiros são responsáveis pela sinalização das vias, pelo engate e desengate de vagões e pela manobra dos veículos ferroviários. Os maquinistas, por sua vez, são responsáveis prioritariamente pela condução dos trens, pela inspeção do estado da composição ferroviária, e conservação da mesma, e também pela manobra dos veículos. 24 Sobretudo dos maquinistas e encarregados, conforme demonstram algumas ações de reconhecimentos de vínculo empregatício com a CSN movidas por ex-manobreiros terceirizados.
} 
ceirização das atividades. A fraca autonomia da contratada na gestão dos serviços caracteriza os casos em que a terceirização não envolve transferência de conhecimentos técnicos complexos, o que facilita a retomada das atividades terceirizadas pela contratante. Num processo ainda pouco claro do ponto de vista de trabalhadores, sindicalistas e operadores do direito, a CSN iniciou desde os anos 2006/2007 um processo de retomada de atividades e funções que ela havia entregue a empresas terceirizadas nos anos 1990 e início dos anos 2000. Na ausência de uma declaração oficial da empresa sobre a mudança, várias explicações e especulações emergiram no intuito de dar conta deste processo de verticalização. Na UPV, grandes contratos com empresas de serviços ${ }^{25}$ foram encerrados nos anos de 2006, 2007, 2010 e 2017. Entre as diversas causas elencadas pelos agentes econômicos e não-econômicos se destacavam: a queda na produtividade ocasionada pela terceirização; a necessidade de maior controle sobre os contratos, evitando burlas; a necessidade de reduzir as queixas, as ações e o passivo trabalhistas na justiça; de conter a ampliação de greves de terceirizados; o encarecimento dos contratos em função da ampliação da dependência em relação à empresa contratada e da perda de know-how da empresa principal ou contratante (Dias, 2013).

A desterceirização ${ }^{26}$ das atividades de manobra ocorreu ainda em 2006, e deu início à reintegração de atividades. No ano seguinte, a manutenção volante ${ }^{27}$ também foi reintegrada aos quadros da empresa principal. Em 2010 a empresa deixou de renovar contrato com uma de suas principais fornecedoras de serviços até então, a italiana Comau, incorporando parte da manutenção realizada na Laminação ${ }^{28}$ aos quadros diretos. Em 2017, a desterceirização en-

\footnotetext{
25 Que chegaram a abranger mais de três mil empregados.

26 Estamos considerando como desterceirização apenas as atividades e funções que a CSN incorporou a seus quadros diretos, uma vez que a empresa, a partir de 2012, também incorporou parte da mão de obra a "seus" quadros por meio de uma joint-venture, na qual possui $50 \%$ das ações. Estes trabalhadores da joint-venture não possuem os mesmos benefícios dos trabalhadores da CSN (Dias, 2018).

27 Que caracterizava um corpo de funcionários qualificados, responsáveis pela manutenção de diversas áreas da usina.

28 A Laminação constitui uma etapa de acabamento da produção de aço. À época, estimava-se que a assimilação de ex-tercerizados tinha sido de cerca de $60 \%$ dos efetivos da contratada. De acordo com alguns entrevistados, a integração apenas parcial de trabalhadores da Comau levou à redução de postos de trabalho de manutenção na CSN, ou seja, a desterceirização foi utilizada como forma de enxugamento dos quadros, em função de um suposto aumento da produtividade: “(...) E estrategicamente a gente [CSN] enxergou que primarizar a mão de obra é mais interessante do que manter um contrato com vocês [Comau] (...) a Comau tinha 800, 900 funcionários, falou assim 'oh a
} 
volveu também a prestadora de serviços japonesa Sankyu, que havia sido desde 2002 a principal fornecedora de serviços terceirizados de manutenção para a siderúrgica. Embora o objetivo deste texto não seja o de discutir com profundidade as causas e consequências do processo de desterceirização ${ }^{29}$, não podemos negligenciar a questão sobre os custos, questão que sempre esteve no cerne da defesa da terceirização. Sendo a terceirização um processo que ocasionaria a redução de custos, podemos afirmar que a desterceirização implicará no aumento dos custos com o trabalho? Partindo da lógica de que a terceirização incide na redução de custos via redução de direitos e benefícios trabalhistas, caso a desterceirização seja realizada com incorporação total dos ex-terceirizados, a tendência seria de aumento do custo com a força de trabalho ${ }^{30}$, uma vez que os trabalhadores passariam a gozar dos benefícios e salários dos quadros da empresa principal. No entanto, tendo em vista a máxima da reengenharia, centrada no "corte de custos" como alvo privilegiado da reestruturação das empresas, como conciliar desterceirização e redução de custos, ou desterceirização e, ao menos, manutenção dos custos ${ }^{31}$ ?

A despeito de a terceirização ter sido quase sempre mecanicamente associada à redução de custos, parte da bibliografia - sobretudo aquela que discute a desterceirização - considera que a gestão subcontratada dos efetivos teria aumentado a insatisfação dos trabalhadores, elevando o absenteísmo, as demissões à pedido do funcionário e as greves, o que teria efeitos sobre a produtividade (Santos e Garrocho, 2013; Dias, 2013). Por outro lado, as ações trabalhistas nas quais a empresa contratante figurava como ré ${ }^{32}$ também tinham um potencial de elevar, ainda que indiretamente, os "custos" da terceirização.

gente entende que se esse cara trabalhar na CSN ele vai ser de $40 \%$ a $60 \%$ mais produtivo.' Então pegaram e fizeram um quadro com 480 pessoas mais ou menos na CSN. Os mesmos 900 da Comau iam ser agora 480, iam dar conta. E ai fizeram um quadro menor na CSN e falaram: "vai valer a pena" (E). Os números indicados pelo entrevistado não são precisos, mas baseado em especulação. 29 Para uma discussão mais atenta à desterceirização e suas causas e consequências, ver Oliveira (2010), Cardoso e Romão (2011), Dias e Oliveira (2012), Dias (2013) e Santos e Garrocho (2013). 30 Desconsiderado o lucro da contratada.

31 Salientamos de imediato que as considerações sobre custos feitas aqui, como em outros autores, é baseada em hipóteses e induções acerca da temática, uma vez que a variável "custo" do trabalho é de difícil estimativa, pois, envolve uma série de outras variáveis e, mesmo dentro das empresas, constituí uma caixa preta a qual poucos tem acesso.

32 Como aquelas nas quais os trabalhadores demandavam reconhecimento de vínculo de emprego com a CSN, e/ou direitos trabalhistas sonegados pelas empresas contratadas. 
O dilema sobre a desterceirização e aumento dos custos com o trabalho como resultado imediato da incorporação de quadros e a reintegração vertical é apenas um falso dilema, porque parte destes processos de desterceirização tem sido realizado simultaneamente à redução de quadros de trabalhadores ${ }^{33}$. Na seção seguinte, e com base na análise do caso da CSN, discutiremos a polivalência como forma efetiva de enxugamento dos quadros, buscando salientar como ela se articula com a desterceirização. Buscaremos ainda apontar como a polivalência é possibilitada tanto por inovações tecnológicas - no caso da manobra - quanto organizacionais - incorporação dos terceirizados aos quadros da empresa principal.

\section{Em direção à polivalência: o operador-mantenedor e o solda- dor-maçariqueiro}

A partir de 2005 começam a aparecer nos boletins do Sindmetal-SF denúncias sobre a imposição pela $\mathrm{CSN}$ de dupla função $0^{34} \mathrm{a}$ seus trabalhadores. Os operadores de algumas áreas eram obrigados a atuar como mantenedores, sobretudo no horário noturno, quando algumas áreas não contavam com plantão de trabalhadores terceiri$\operatorname{zados}^{35}$. Em 2005 uma nota do boletim sindical trazia a denúncia de que trabalhadores da Gerência de Laminação à Frio estariam sendo coagidos a exercer funções de operadores e de mantenedores, sob ameaça de demissão ${ }^{36}$. No mês de julho, a mesma prática era denunciada na Gerência de Decapagem Ácida (GDA), também na área da Laminação, que devido à falta de mão de obra, estaria criando turnos de 12 horas e obrigando eletricistas a fazerem o treinamento de ope-

\footnotetext{
33 Ver Dias e Oliveira (2012).

34 Ações contra a "dupla função" ou "acúmulo de funções" na CSN aparecem em alguns acórdãos disponíveis no site do TRT 1. Em geral, há vedação ao acúmulo de funções pelos tribunais, exceto nos casos em que a empresa paga um adicional, ou a diferença entre a função para o qual o trabalhador foi contratado e aquela(s) que ele exerce(u), desde que o exercício destas outras funções tenha ocorrido de maneira regular. Cabe ao trabalhador comprovar o exercício regular destas atividades e funções para além daquelas para o qual foi contratado.

35 A consulta à Classificação Brasileira de Ocupações (CBO) nos anos de 1982, 1994 e 2002 demonstra parte da transformação sofrida no desempenho das atividades de operação e manutenção, com ampliação das obrigações e/ou incorporação de atividades de outros grupos e funções. A CBO é um documento que descreve e sistematiza as funções, atividades e conhecimentos das ocupações no mercado de trabalho brasileiro. $\mathrm{O}$ documento se baseia na existência de determinada atividade profissional, e não em sua regulamentação.

36 Boletim 9 de novembro de 15 de setembro de 2005.
} 
ração de painel de máquinas, e inspetores a assumir atividades de técnicos de processo ${ }^{37}$. Em 2006, sob matéria de título "CSN: dupla função e só um salário” o boletim sindical afirmava que:

Em algumas gerências da CSN os trabalhadores têm exercido dupla função e só recebem um salário. Um exemplo disso são alguns eletricistas que além do seu trabalho, fazem a função de operadores. É um absurdo que numa empresa como a CSN os trabalhadores ainda tenham que passar por esse desgaste. Sabemos quais gerências isso vem acontecendo e o Sindicato tomará providências para que essa prática da empresa acabe. (Boletim 9 de novembro de 16 de novembro de 2006)

\section{É provável que antes mesmo de meados dos anos 2000 a CSN} já investisse na tentativa de introduzir a multifuncionalidade entre seus funcionários de operação e de manutenção ${ }^{38}$. A introdução de métodos japoneses na empresa, tais como TQC e $5 \mathrm{~S}^{39}$, bem como a padronização dos procedimentos e codificação dos conhecimentos na usina através do SIGMA ${ }^{40}$ remonta os anos 1980 e os anos 1990. Sobre este processo de padronização e sua influência na produção siderúrgica, um trabalhador destacou:

(...) tinha os equipamentos de prevenção, que era capacete, óculos, mas não existia padrão pra você trabalhar, você ter um livro, pra

37 Boletim 9 de novembro de 28 de julho de 2005.

38 Na pesquisa sobre as ocupações, embora na descrição das atividades de "Operação de Máquinas fixas, em geral" aparecesse desde as CBOs de 1982 e 1994 a responsabilidade por efetuar "a manutenção e pequenos reparos nas máquinas", a enumeração daquilo que é englobado por esta atividade secundária é, naqueles documentos, restrita a três ações (lubrificação, ajuste de peças e consertos). Em 2002, para esta mesma ocupação, a descrição específica das atividades no tópico "realizar manutenção de rotina" enumera dezessete ações e/ou responsabilidades, ou seja, quatorze a mais do que aquelas já indicadas nos documentos anteriores. No caso da descrição da ocupação de Mecânicos de manutenção de máquinas, há aparentemente uma inflexão no processo de polivalência. Enquanto nos CBOs de 1982 e 1994, a descrição das atividades destes profissionais incluía, além das atividades de conservação e reparo de máquinas equipamentos, a possibilidade de execução de atividades de soldador (Pode operar equipamentos de soldagem a oxigás ou eletricidade), este item não aparece no CBO de 2002, embora as entrevistas realizadas tenham indicado a realização de atividades de solda e de manutenção elétrica por mecânicos de manutenção (Grifo nossos). De acordo com a CBO de 1982, a descrição das atividades das ocupações, quando precedida da palavra "Pode", designa tarefas consideradas acessórias, secundárias e/ou opcionais. Essas atividades seriam não-essenciais à ocupação, porém manteriam certa "analogia" em relação às atividades principais (Classificação Brasileira de Ocupações 1982, 1994 e 2002).

39 O $5 \mathrm{~S}$ é uma metodologia japonesa de organização do ambiente de trabalho e aumento da produtividade.

40 O SIGMA consiste em um sistema de gerenciamento da manutenção que se ocupa do controle, da geração e análise de dados que orientam ações de realização de manutenção para preservar as máquinas e reduzir e/ou minimizar os defeitos. A redução de custos neste sistema se faz a longo prazo, com a melhoria da qualidade e extensão da vida útil do equipamento. 
Desterceirização e flexibilidade: retorno à integração vertical e o impulso à polivalência.

saber qual seu equipamento, pra saber onde mexer, não existia isso. Você tinha que chegar, aprender com o antigo da área, se ele quisesse te explicar ele explicava, se ele não quisesse te explicar não tinha quem explicava, e você tinha que estar sempre atrás de um cara, tentando aprender o que tinha que fazer (...). (U) ${ }^{41}$

\section{E também:}

Antigamente, antes do SIGMA eu conhecia o equipamento X lá, aí eu era o papão daquilo ali, aí não passava a informação para ninguém. Aí toda vez que dava problema, 'oh chama só o [nome do entrevistado], que sabe arrumar, chama o [nome do entrevistado] aí'. (...) Todo importante, chego lá, conserto. Aí: 'Não pode [a empresa] perder esse cara não'. Escondia desenho. Agora não tem mais jeito, qualquer pessoa que chega lá, tá a descrição todinha de tudo que tem que ser feito. Até a calibração do equipamento. Fala assim 'ah não conheço esse equipamento não' (...) você aperta o botão tal. Nas minhas áreas responsabilidade tem tudo isso aí tá. Aí você aperta o botão assim, se você responder tal lá, porque você aperta esse aqui aí calibra aqui, coloca solução embaixo e tal, aperta continua e vai calibrando. Qualquer pessoa, até o operador pode fazer o serviço. $(\mathrm{O})^{42}$

O SIGMA, utilizando um sistema de programação das intervenções, levou à padronização dos procedimentos e ao aumento da vida útil dos equipamentos, reduzindo a necessidade de trabalhadores de manutenção corretiva e de emergência, bem como permitindo que operadores com um conhecimento "superficial" de manutenção conseguissem realizar tarefas que antes integravam os saberes e os conhecimentos tácitos oriundos da experiência dos mantenedores ${ }^{43}$. A "aceitação" do SIGMA pelos operadores foi lenta, pois, o sistema entrava em choque com a cultura e com os tempos da operação. $\mathrm{O}$ planejamento e a programação da manutenção facilitavam até mesmo a divisão da atividade, entre concepção e execução, que deu im-

41 Entrou na CSN no final dos anos 1970, desempenhando inicialmente atividades de manutenção e, a partir dos anos 1990, com a expansão da terceirização destes serviços, tornou-se operador de ponte rolante da empresa.

42 O entrevistado entrou na usina em 1980 na manutenção elétrica.

43 Isto porque o SIGMA trabalha com uma codificação e planejamento de ações estilo "lista de itens". 
pulso à terceirização das atividades de execução das tarefas ${ }^{44}$. Por outro lado, a profissionalização dos fornecedores de equipamentos fez com que, na compra das máquinas, já viessem “amarradas" todas as informações e especificações sobre os itens, tempo de vida útil, garantia e periodicidade das intervenções.

As mudanças tiveram particular impacto sobre a manutenção de equipamentos, que passou a privilegiar a preservação do equipamento para evitar "gambiarras" e ampliar a vida útil das máquinas ${ }^{45}$. Este processo de mudança foi acompanhado nos anos 1990 pela reestruturação das seções e áreas da empresa, com a eliminação das superintendências de manutenção ${ }^{46}$, e subordinação dos trabalhadores de manutenção às Superintendências de Operação das áreas.

Embora não tenhamos conseguido precisar o início destas práticas de polivalência na empresa, é possível afirmar a partir das entrevistas e dos boletins sindicais que em meados dos anos 2000 o esforço em direção à multifucionalidade dos quadros persistia e se ampliava. As denúncias de dupla função entre os quadros da CSN aparecem de maneira regular nos boletins, principalmente no treinamento dos funcionários de manutenção da empresa para o acúmulo de atividades de operação. A dupla função em sentido inverso, do treinamento de operadores para atuar na manutenção (operador-mantenedor), também era praticada em algumas áreas e gerências. Um dos entrevistados afirmou que a dupla função sofreu grande resistência dos operadores, e que por isto ela não havia sido implantada na área em que trabalhava. Como mencionamos previamente, grande parte dos operadores da CSN, em especial aqueles com mais tempo de "casa", tinham sido outrora mantenedores da FEM ou da CSN, no entanto, em meados dos anos 2000 muitos já não executavam as funções de manutenção há algum tempo e não dominavam mais a prática do ofício. Ao "especializar" a manu-

44 Além da manutenção, o SIGMA reduziu também a necessidade de inspetores de área, que realizavam os serviços de "relatar os problemas", de levantamento de atividades a serem desempenhadas, e de elaboração das ordens. Os operadores passaram a acumular também, em alguns casos, a atividade de inspeção das áreas, e os inspetores que restaram, deixaram de ter contato e conhecimento do equipamento e da área.

45 Enquanto a manutenção corretiva é acionada nos casos em que o equipamento apresenta falhas e danos, que causam perdas não previstas à produção, as manutenções preventiva e preditiva, realizadas periodicamente, atuam no sentido de garantir a longevidade das máquinas.

46 Desta forma, a reformulação extinguiu várias superintendências de manutenção na CSN, tais como a Superintendência de Mecânica, Superintendência de Instrumentação, Superintendência de Eletrônica, que foram substituídas por superintendências de área, ou pelas Superintendências de Operação. 
tenção a terceirização dificulta o acúmulo de funções, seja do ponto de vista do conhecimento técnico necessário aos funcionários, de sua disposição em cooperar com a intensificação do trabalho, ou do ponto de vista das antigas barreiras jurídicas à expansão da terceirização nos quadros diretos das empresas.

Sobre as investidas da CSN em implantar a multifuncionalidade e as resistências dos funcionários diretos a este processo, um dos entrevistados afirmou:

[...] Então o que eles fizeram [...] colocou um mecânico e um eletricista com um operador para aquele operador aprender com o passar do tempo, a sanar um probleminha pequeno de elétrica, e um probleminha pequeno de mecânica. E depois demitiu o mecânico e o eletricista, para o operador fazer tudo. Aonde fez a manutenção autônoma. Colocou três para trabalhar junto. Mas a manutenção autônoma, o operador tem equipamento que ele não consegue largar o equipamento para, para fazer a manutenção (Ex-sindicalista do Sindmetal-SF $)^{47}$.

\section{Outro entrevistado afirmou que:}

A manutenção você encontra o equipamento parado tem que resolver. $\mathrm{O}$ operador parou o equipamento, ele quer que alguém resolva, entendeu. Tentaram fazer uma manutenção, é operação, como é que é [...] operador de manutenção [...] é outro nome, não é bem esse não [...] que ele queria pegar o pessoal que veio da manutenção e aproveitar para resolver os problemas que pintassem na área [...] Mas isso não deu certo. Não dá certo, porque ou você faz uma coisa ou você faz outra. Não tem como você operar a máquina e parar tudo para ir lá resolver problema da área. Até porque tem sempre um que não veio da manutenção. Aí o cara fala assim: 'aí oh, tem um probleminha lá'. Aí o cara vai resolver o problema. Nós temos amigos aí [operadores de máquinas] que até hoje ficam lá com a ferramenta na mão. Aí você vê gente subindo, fica só mandando, só gerenciando e o bobo fica lá, fazendo a função para o cara. Então não dá. Aí esta ideia não deu certo [...] acho que é operador de manutenção, é uma coisa assim. $(\mathrm{L})^{48}$

47 O entrevistado entrou na CSN no final dos anos 1970 na função de técnico de indústria. Passou por diversas áreas e funções, e foi Vice-presidente do Sindmetal-SF durante os anos 2000.

48 O entrevistado "L" entrou na CSN no final dos anos 1980 na função de eletricista, tra- 
O relato do trabalhador e do sindicalista trazem referências importantes para mensurar o impacto da polivalência entre os funcionários. Em princípio, nos dois trechos há uma ênfase nas dificuldades em acumular e sincronizar as atividades de operação e manutenção que são de natureza operacional e técnica. A dificuldade de ordem prática aparece quando há a indicação de que o operador tem que "largar o equipamento", ou quando o trabalhador diz que não é possível "operar a máquina e parar tudo para ir lá resolver problema da área”. Por outro lado, a execução de atividades de manutenção e operação parece se desenvolver a partir de lógicas antagônicas relativas à cultura do trabalho dentro da produção: para a manutenção, é preciso parar as máquinas e, ainda que leve tempo, é preciso realizar a manutenção preventiva ou a reparação de maneira que se preserve o uso pelo maior tempo possível ${ }^{49}$. O operador por seu turno está preocupado com a perenidade da produção e, portanto, a parada das máquinas implica, dentro da especialização das funções, a suspensão de suas atividades básicas e da produção. Em outro depoimento, o conflito latente subjacente às dinâmicas e tempos distintos dos ofícios de mantenedores e operadores de máquinas no chão de fábrica ganha a superfície, e aparece de forma direta nas relações entre estes dois grupos de trabalhadores:

A operação ela encara o pessoal da manutenção como bicho papão né, eles não gostam não. (...) Quando o pessoal da preventiva chega para fazer algum serviço eles já coloca a mão na cabeça: 'ai meu deus do céu, o que que você tá querendo aqui?' Pessoal: 'quero mexer nisso aqui'. 'Pô logo esse? Não, não dá para mexer não.' Ele não admite (...) para ele [operador] só pode mexer quando está tudo ruim, enquanto tá bom tem que estar liberado para operar. Ele não entende esse controle do SIGMA que tem que, para ele operar 10

\footnotetext{
balhando no turno de manutenção elétrica. Com o fim do turno de manutenção, passou a trabalhar no horário diurno e, por volta dos anos 2000, passou para a operação de equipamentos.

49 Esta lógica antinômica e os diferentes tempos a partir dos quais se desenvolvem as atividades de manutenção e de operação ficam particularmente explícitos na narrativa de um dos entrevistados, que mencionou que "O gerente que vem da parte de operação ele não tem paciência, esperar o planejamento, ele quer resultados rápidos, diferente dos gerentes da manutenção". Em outro trecho “(...) A operação não gosta de parar equipamento (...) o gasto com a manutenção é muito grande, tem que gastar dinheiro e deixa de produzir [nas paradas de manutenção] (...)” (O). Para o entrevistado, os trabalhadores de operação consideravam que a operação colocava "mais dinheiro na usina" e a manutenção só "tira". Esta visão seria equivocada, pois segundo "O", a longo prazo as manutenções preventiva e preditiva reduziam os custos com a perda ou parada dos equipamentos.
} 
anos né na vida útil, tem que trocar um contatozinho (...) requer a parada do equipamento né (...) Mas acho que com o passar do tempo eles [operadores] estão aceitando mais essa, esse processo do SIGMA, de ter que fazer a intervenção nos equipamentos. Mas é difícil, eles não aceitam não. Eles gostam quando dá esse problema da emergência, aí eles trabalham até o ponto que não dá mais. Deu problema, pum, parou. Aí eles largam tudo, aí a gente vem trabalhar e eles ficam atrás da gente: ‘termina logo, termina logo' (...). (O)

A polivalência de acordo com os trechos acima se desenvolve a partir do trabalhador de operação da CSN. O conhecimento para atuar como mantenedor seria adquirido seja ao colocar lado a lado operadores, mecânicos e eletricistas, seja ao recorrer aos conhecimentos prévios sobre a manutenção daquele trabalhador que havia acumulado conhecimento técnico e/ou prático na atividade de manutenção antes de se tornar operador ${ }^{50}$. A inexistência de conhecimento prévio ou de treinamento nas atividades de manutenção limita a polivalência para os operadores da CSN, sobretudo entre os mais jovens, pois parte dos operadores de máquinas da siderúrgica nos anos 1990 e no início dos anos 2000 havia exercido funções de manutenção antes que a empresa iniciasse um processo de ampliação da terceirização destas funções. No entanto, mesmo entre aqueles que haviam desempenhado funções de manutenção anteriormente, permanecia a necessidade de recuperar o conhecimento sobre o desempenho da função. Finalmente, os trechos sugerem resistências à polivalência na medida em que, ao exercer a dupla função de operador-mantenedor, o trabalhador acumula responsabilidades, sem necessariamente garantir uma elevação do status profissional ou uma elevação salarial correspondente ao aumento da intensidade do trabalho.

Outro funcionário que passou à CSN depois da desterceirização também apontou as dificuldades não apenas da siderúrgica em implan-

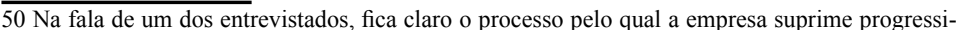
vamente a manutenção terceirizada no período noturno, substituindo-a pela manutenção realizada por trabalhadores do quadro direto, ex-mantenedores de equipamentos transformados em operadores de máquinas: "(...) eu entrei no diurno, depois eu trabalhei na manutenção elétrica noturno, depois acabaram com a manutenção elétrica do turno - jogaram todo mundo de dia (...) Quando apareceram as vagas na operação, eles deram preferência pra quem já estava trabalhando ali, quem já conhecia o sistema. Assim, eram equipamentos que a gente já fazia a manutenção, então, nós já sabiamos como funcionava. Então, era só uma adaptação operacional. Então pra mim foi "a mão na roda" (L).
} 
tar a polivalência entre seus quadros, mas da própria terceirizada em praticá-la com trabalhadores subcontratados de outras empresas:

(...) Eles [altos funcionários da CSN] começaram a forçar o pessoal. E o pessoal que era mais antigo falaram: 'ah eu não vou fazer', bateu o pé e não quis fazer. E aí depois foram correr atrás do sindicato, aí falaram: 'não, aí é desvio de função'. Aí já era. Porque o seguinte, por exemplo, o soldador da Comau, ele soldava e ele cortava com o maçarico, o soldador-maçariqueiro ${ }^{51}$. Quando a Comau ia para um reparo geral onde ela precisava contratar mais gente de fora, e ela não conseguia contratar soldador suficiente ela contratava uma empresa que fornecia os soldadores. Aí quando eu falava para o camarada cortar, ele: 'não corto, eu sou só o soldador'. Aí falava para o outro cara soldar: 'eu não soldo, eu só sou maçariqueiro'. Só que a Comau pagava o dobro do funcionário próprio para este cara. Só que aí eu tinha que chamar um cara da Comau que ele cortava e soldava, porque eu precisava dele atuando nas duas frentes ao mesmo tempo, e o cara da outra empresa era um ou outro. Então ele não desviava a função dele. E aí na CSN aconteceu isso, o operador falou 'oh eu não vou trabalhar na manutenção, porque é desvio de função.' $(\mathrm{E})^{52}$

Tanto as entrevistas quanto os boletins sindicais indicam que o desempenho de diferentes funções tem sido nos últimos anos objeto de disputa entre o sindicato, a CSN e seus funcionários, sobretudo os mais antigos, e que durante a primeira década dos anos 2000, havia resistências a este processo. No entanto, não conseguimos nesta pesquisa determinar a extensão do suposto "fracasso" indicado por entrevistados na prática e expansão da multifucionalidade en-

51 A categoria Soldador inclui as atividades de soldagem de peças e conjuntos mecânicos, através do uso de diferentes fontes de calor. O oxicortador (à mão, e à máquina) é o profissional responsável pelo corte de diferentes materiais como o ferro, metais e sucatas. A ocupação "Soldador" aparece na CBO de 1994 e 2002 com algumas diferenças na definição em relação a 2002. Enquanto a tabela de atividades da CBO 2002 descreve a responsabilidade do Soldador no preparo dos equipamentos para "soldagem e corte", no documento de 1994, a descrição detalhada indica que este profissional "(...) Pode marcar as peças e cortar o metal por meio de maçarico" (Grifos nossos). Na CBO 2002, além de a atividade de corte aparecer inequivocamente como uma das atribuições da ocupação de soldador, há intensa transformação desta categoria de trabalhadores. Em decorrência das fusões com outras categorias e das supressões de títulos, das dez ocupações arroladas no grupo "Soldadores de Oxicortadores" em 1994, apenas 5 permaneceram como ocupações no grupo intitulado "Trabalhadores de soldagem e corte de ligas metálicas" em 2002. (Classificação Brasileira de Ocupações 1982, 1994 e 2002).

52 Entrou na UPV no final dos anos 2000 como terceirizado da empresa Comau na função de mecânico de manutenção. Chegou a galgar cargo de chefia na contratada. Com o fim do contrato e a desterceirização, foi incorporado nos quadros da CSN. 
tre os quadros de operação e manutenção. No entanto, segundo um entrevistado aposentado da siderúrgica, que atua hoje em dia como advogado trabalhista, as ações judiciais de trabalhadores contra o acúmulo de funções na empresa estão cada vez mais rarefeitas, pois os "jovens" tendem a naturalizar a polivalência, em contraste com os trabalhadores de sua geração, mais "antigos", que já "conheciam as regras do jogo" ${ }^{\prime 3}$.

A multifuncionalidade neste contexto parece ser uma ferramenta de enxugamento das empresas mais eficiente do que a terceirização, pois a segunda pode significar tão somente transferência de quadros ${ }^{54}$. Sobre o significado da nova organização do trabalho no Japão e as resistências dos trabalhadores a elas opostas, Coriat (1994) afirma:

(...) Este movimento de desespecialização dos operários profissionais e qualificados, para transformá-los em trabalhadores multifuncionais, é de fato um movimento de racionalização do trabalho no sentido clássico do termo. Trata-se aqui, também - como na via taylorista norte-americana -, de atacar o saber complexo do exercício dos operários qualificados, a fim de diminuir seus poderes sobre a produção e aumentar a intensidade do trabalho. E os operários qualificados viveram efetivamente este movimento de desespecialização como sendo um ataque a seu exercício profissional e ao poder de negociação que este mesmo exercício autorizava. Através de diversos meios, entre os quais, é claro, a greve, eles se opuseram a este movimento. (Coriat, 1994, p. 53)

A desespecialização significava o rompimento com as práticas anteriores, e representava um ataque às qualificações e à organização existente. A reintegração das atividades de controle de qualidade ao processo exigia novas habilidades dos operadores que conduziram à:

(...) reintrodução nas funções dos operadores diretos de tarefas ou funções de diagnóstico, reparo e manutenção; a autonomação e a

53 Que trabalharam na empresa no período de 1980 até a primeira década dos anos 2000. As "regras do jogo" neste caso remete a uma apreensão do Direito estimulada pelos boletins sindicais - a vedação à dupla função, e ao desempenho, sem contrapartidas, de funções não indicadas no contrato de trabalho -, mas também à percepção de uma geração de trabalhadores sobre os "acordos" tácitos que marcavam a relação com a empresa.

54 Embora em geral, também implique em redução de postos de trabalho. 
auto-ativação só tem sentido e eficácia se os operadores diretos têm igualmente o encargo da observação e da manutenção quotidiana das máquinas. (Coriat, 1994, p. 58)

Não é apenas na CSN que os operadores das linhas de Laminação são impelidos a assumirem o papel de mantenedores. Em pesquisa sobre as mudanças no trabalho na siderúrgica belga Cockerill Sambre, Lomba (2005) chama a atenção para a importância da imposição da multifuncionalidade aos trabalhadores das laminadoras da empresa e seu papel no redimensionamento dos quadros de funcionários e na redução de custos.

$\mathrm{Na}$ Laminação, a automatização dos processos reduziu drasticamente o número de equipes e de trabalhadores, e a maior parte dos operadores foi substituída por processos automatizados. A manutenção de equipamentos especializada e outras tarefas auxiliares à produção, por sua vez, sofreram intenso processo de terceirização (Lomba, 2005). Nestas condições de diminuição da autonomia e da ingerência do trabalhador sobre o processo de produção, houve uma depreciação do status dos operadores, que passaram da condição de trabalhadores white-collar para a de blue-collar, ou de um trabalho predominantemente "intelectual" para o "manual" 55 . Com o objetivo de poupar tempo e força de trabalho, desde 1994 a siderúrgica belga optou pela superação das divisões entre as atividades de controle de qualidade, manutenção e produção, de maneira a permitir que durante as paradas da produção, os operadores pudessem se ocupar de tarefas de manutenção que não exigem habilidades específicas, enquanto funcionários de manutenção e de controle de qualidade poderiam acionar os equipamentos de produção em operações de menor complexidade (Lomba, 2005, p. 82). De maneira similar a polivalência parece ter se intensificado na CSN, principalmente após a desterceirização dos trabalhadores da subcontratada Comau. No relato de um ex-trabalhador da prestadora de serviços que deixou a usina após o fim do contrato de prestação de serviços da terceiriza$\mathrm{da}$, as mudanças em direção à multifucionalidade entre os mantene-

$55 \mathrm{Na}$ prática, além de salários menores, os trabalhadores manuais estão sujeitos ao pagamento por hora, enquanto os outros recebem salário mensal, independentemente da demanda de produtos (Lomba, 2005). 
Desterceirização e flexibilidade: retorno à integração vertical e o impulso à polivalência.

dores se intensificaram na CSN após a desterceirização:

[...] Maçariqueiro agora é tudo uma coisa só: solda e corta, mesma coisa. Corta com o maçarico e solda. Antes tinha: maçariqueiro fazia uma função e soldador fazia a dele. Agora não, um faz tudo. E agora na CSN [...] tem setor dentro da CSN agora que eu fiquei sabendo, depois que eu saí da Comau, que o soldador, acabou esse negócio, tem setor que não tem mecânico 2 , ele tem que cortar, soldar, e trabalhar de mecânico [...] O soldador na minha época quando eu estava lá dentro ainda, ele soldava e cortava com o maçarico, agora ele tem que fazer mais uma função, ele tem trabalhar como mecânico [...] Tem setor dentro da CSN que está assim [...] E o salário, aquela merreca. $(\mathrm{A})^{56}$

No relato do trabalhador, as transformações práticas no ofício de maçariqueiro levaram sucessivamente à incorporação de novas atividades, fazendo emergir na época em que trabalhava na indústria, a função de soldador-maçariqueiro e, posteriormente à sua saída da empresa, a de soldador-maçariqueiro-mecânico. Se entre os funcionários da CSN a prática de atividades de operador-mantenedor é alvo de resistência, entre os terceirizados, elas eram anteriormente limitadas. A orientação dos tribunais, em convergência com a súmula n³31 até o ano 2017, tendia a considerar lícita apenas a terceirização de atividades-meio, vedando a extensão da prática para as atividades-fim da empresa. Mesmo que entre os magistrados na Justiça do Trabalho ao longo dos anos 2000 permanecessem divergências em relação ao caráter finalístico da manutenção, com relação à operação de equipamentos não havia muitas dúvidas sobre a natureza eminentemente essencial da atividade. Embora tenha ocorrido terceirização de atividades de operação mesmo antes da Lei 13.429, ela parecia residual em outras empresas, e inexistente na $\mathrm{CSN}^{57}$. A limitação da terceirização às atividades-meio, portanto, impedia - ao menos em tese - a alocação de funcionários subcontratados qualifi-

56 Entrou na usina no final dos anos 1980 através de empresa contratada, na Fundição, unidade extinta nos anos 1990. Com o fim das atividades da Fundição, foi contratado para a manutenção de linhas férreas da FEM, e depois para a manutenção de máquinas, até a extinção da FEM em 2001/2002, quando foi demitido e deixou a empresa.

57 Ao longo da pesquisa não foram encontrados registros de terceirização na atividade de operação de máquinas. 
cados de manutenção para realizar atividades de operação de máquinas. Se tecnicamente a figura do "mantenedor-operador" se afigura como mais plausível, juridicamente, o "operador-mantenedor" evitava ações e processos judiciais de demanda por reconhecimento de vínculo empregatício. A desterceirização, neste sentido, eliminou as barreiras à ampliação do acúmulo de funções entre os mantenedores recém-contratados pela siderúrgica.

A partir do material de pesquisa pudemos identificar um impulso à polivalência nos anos 2000, sobretudo na Laminação, onde ocorreu em 2010 a desterceirização de grande parte dos efetivos, com redução do número de trabalhadores na área. É possível supor que a polivalência entre os ex-terceirizados tenha sido uma forma privilegiada de garantir a redução, ou ao menos a manutenção de custos com força de trabalho, sem prejuízo do desempenho operacional da usina. A despeito das limitações técnicas dos operadores, eles eram funcionários do quadro direto da empresa, e não haveria, portanto, limites jurídicos à ampliação de suas funções em direção às atividades não essenciais, enquanto o contrário, no caso dos terceirizados, não era verdadeiro. Em várias ocasiões em que os trabalhadores mencionaram a polivalência nas funções de operação e manutenção, a transversalidade começava pelo operador, ou trabalhador do quadro da CSN. Isto não significa que não houvesse polivalência entre os trabalhadores terceirizados, mas ela se caracterizava mais pelo acúmulo de diferentes atividades de manutenção como o soldador-maçariqueiro, ou o mecânico-eletricista. No caso das atividades de manobra, a desterceirização como forma de facilitação do acúmulo de funções apareceu de maneira mais clara.

\section{O manobreiro-maquinista}

$\mathrm{Na}$ atividade de manobra, a incorporação dos ex-manobreiros terceirizados aos quadros da empresa principal sugere um "reconhecimento" que parece ter desempenhado um papel central na redução das resistências à função de maquinista-manobreiro. A elevação do status dos ex-terceirizados aparece no depoimento de um sindicalista do Sindmetal-SF: 
A Gil [Gerência de Operação de Transporte Interno] teve dois processos que eu me lembre (...) há muito tempo atrás ela passou para a Ormec. Depois, viu-se que não foi eficiente manter daquela forma. Por que? Pro cara ser manobreiro, ele tem que saber bastante coisa, tipo: quais são as linhas, quais são as vias permanentes, a mudança de via ali. Não é pegar qualquer pessoa e colocar, tem que ter um treinamento. E mexe com um produto que ela não brica, ele não bilisca, ele aleija ou mata a pessoa, que é o vagão. É 100 toneladas e tal. Então viu-se que não estava tendo uma continuidade de formação de profissional. Aí, com isso desterceirizou. A CSN fez um trabalho de primarização e voltou, e muitos deles [manobreiros] hoje são tudo maquinistas, porque cresceram com este processo (...) A empresa continua mantendo e eles como maquinistas e manobreiros, e eles tem crescimento dentro da própria empresa. (Sindicalista do Sindmetal-SF $)^{58}$

$\mathrm{Na}$ desterceirização dos manobreiros está implícita duas formas de reconhecimento e elevação do status simultaneamente: a passagem para os quadros diretos da empresa é acompanhada de uma ascensão na carreira, representada pela conquista do posto de maquinista-manobreiro. Em contraste com os manobreiros, para o maquinista da CSN a realização de tarefas de manobra possivelmente implicava um rebaixamento do status, bem como um acúmulo de responsabilidade e elevação do risco de acidentes.

As delimitações entre as funções "maquinista" e "manobreiro" têm se diluído nos últimos anos e predomina cada vez mais na atividade dos maquinistas de pátio a polivalência. Mudanças tecnológicas permitiram uma reestruturação importante nestas categorias de profissionais nos últimos anos, de maneira que maquinistas e manobreiros "são atualmente escalados para exercer ambas as funções em períodos alternados" (Nozoe et al., 2003, p. 245). Nas atividades relativas ao transporte ferroviário as mudanças não atingiram apenas maquinistas e manobreiros, mas também a função de agente de pátio. Atualmente estes últimos, além de desempenharem atividades tais como liberação de trens para partida, controle de cargas e de entrada

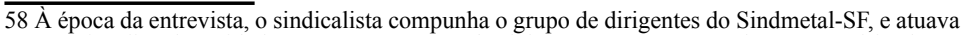
no setor jurídico da entidade. Entrou na UPV no final dos anos 1970 através de uma terceirizada, na função de servente. Na CSN, chegou a alcançar o posto de supervisor de entrepostos. 
e saída das composições do pátio, ainda têm que se encarregarem de atividades de manobra (NOZOE et al., 2003, p. 245).

Em documento intitulado Diagnóstico da Formação Profissional / Ramo Metalúrgico elaborado por pesquisadores da CUT e da Rede Interuniversitária de Estudos e Pesquisas sobre o Trabalho, o depoimento de um operador de tráfego de uma siderúrgica permite matizar o processo:

Antigamente, para trabalhar numa locomotiva eram três pessoas, dependendo eram quatro: o manobreiro, o auxiliar e o maquinista, Aí, tiraram o auxiliar. Ficaram só dois. Cada um tinha sua lanterna ou rádio. Hoje não existe mais lanterna. $\mathrm{O}$ manobreiro entrava na expectativa de subir. Entrava como manobreiro, ia para auxiliar ou para revistador, depois para maquinista. Hoje em dia, não. Ele vai de manobreiro para manobreiro-maquinista. É que inventaram um robozinho, depois da privatização. Inventaram um controle e ele opera a máquina sozinho. (Diagnóstico da Formação Profissional / Ramo Metalúrgico, 1999, p.166)

As entrevistas na CSN apontam que desde a desterceirização em 2006, e com a ajuda do controle automatizado das locomotivas, parte dos ex-manobreiros terceirizados se tornaram "Operadores de máquinas 2", que implicava no desempenho de atividades simultâneas de maquinista e manobreiro. De acordo com uma das entrevistas os mais "jovens" 59 eram "preferidos" para assumirem os postos de manobreiro-maquinista na CSN quando da desterceirização. O desempenho das duas funções elevava ainda mais o risco de acidentes:

Mas maquinista quando tá no controle remoto, o maquinista que faz tudo ué. O maquinista no controle remoto tem que fazer o serviço de maquinista e o serviço manobreiro. E é mais difícil porque muitas vezes eu tenho que ficar aqui e a máquina vai embora. Eu tenho que ver minha máquina lá. Por isso que dá acidente. Por isso que controle remoto é só em área. Eles tinham que acabar com o controle remoto também [...] é perigoso [...] já é costume já. Já aconteceu do próprio colete do maquinista, nisso que ele fez um negócio assim

59 O entrevistado refere-se a "jovens" no sentido biológico - trabalhadores com menos de 30 anos -, e no sentido de indicar trabalhadores recém-incorporados aos quadros da empresa principal. 
o controle e tal, o colete dele puxou a alavanquinha do acelerador, aí a máquina andou. Por causa de uma roupa [...] se ele esbarrar na manete ela solta o freio e acelera. $(\mathrm{N})^{60}$

Não são todos os pátios ferroviários ${ }^{61}$, no entanto, que possuem controle automático das composições ferroviárias e, portanto, que manobreiros assumem ao mesmo tempo a função de maquinistas. É possível que com a destercerização, e a transformação de parte dos manobreiros terceirizados em manobreiro-maquinista, a CSN tenha conseguido reduzir os quadros responsáveis por estas atividades. A desterceirização também pode ter atuado de maneira eficiente na redução da oposição à dupla função entre os trabalhadores por uma razão simples: os manobreiros, ciosos de se tornarem maquinistas e recém-incorporados aos quadros da contratante provavelmente ofereceram menor resistências à dupla função, e à intensificação do trabalho e dos riscos.

A incorporação aos quadros da CSN não garantiu aos ex-manobreiros da Ormec um salário "compatível" àquele dos "funcionários CSN". Em função disto, os trabalhadores e o Sindmetal-SF lutaram anos seguidos contra a defasagem salarial estabelecida entre os ex-terceirizados e outros efetivos na UPV ${ }^{62}$. Os processos de desterceirização da guarda patrimonial e dos manobreiros foram controversos e geraram durante anos uma série de medidas do sindicato para sanar os problemas deles advindos. Ao falar sobre estas desterceirizações, um sindicalista do Sindmetal-SF destaca que:

[...] foi uma primarização também que a CSN fez da guarda que criou muito problema e agora que deu uma atenuada. E o pessoal da GIL que são os manobreiros e são os maquinistas, também têm reclamado também, que foi uma primarização que você cria um problema na própria área dos que vieram e dos que já estão lá. Porque

60 Entrou na usina por volta de meados dos anos 2000. Trabalhou alguns anos como manobreiro e socador de linha de empresa contratada. Com a desterceirização da manobra, passou para a CSN, tornando-se manobreiro-maquinista.

61 Segundo um entrevistado, existem três pátios de manobra na usina: o de abastecimento de matérias-primas, o ciclo do gusa, e o escoamento de produto acabado. Cada pátio possui uma quantidade de máquinas ferroviárias e vagões para o transporte de insumos e produtos.

62 A defasagem salarial atingiu primordialmente os trabalhadores da GIL que haviam sido desterceirizados. A partir de 2006 , com a incorporação dos manobreiros ao quadro direto da CSN, a necessidade de realinhamento salarial tornou-se uma das principais lutas do Sindmetal-SF. 
os que vieram acabam ganhando menos fazendo a mesma função. Você cria ali conflitos entendeu. Então a empresa fez estudos para tentar equalizar esta situação aí. Só que a empresa trocou o RH dela de novo né [...] (Renato Soares ${ }^{63}$, ex-presidente do Sindmetal-SF)

Para o entrevistado, o impasse sobre a situação dos manobreiros e da guarda patrimonial também era fruto da ausência de uma política de Recursos Humanos coerente e duradoura. De 2006 a 2011 a CSN teria alterado por quatro vezes seu Gerente de RH. Os problemas enfrentados com a primarização na manobra, entre eles, a manutenção dos salários pagos pela contratada, criou distorções em relação aos salários praticados no quadro da CSN.

A situação dos manobreiros incorporados aos quadros da CSN ocupou dezenas de boletins sindicais anos após o processo de desterceirização em 2006. À época da desterceirização as diferenças salariais possivelmente foram tratadas como conjunturais. Em 2010, a despeito das denúncias do sindicato, as diferenças continuavam:

Diferença salarial na GIL. Há vários anos fazemos reuniões com o RH da empresa sobre a distorção salarial na GIL, principalmente com os manobreiros e maquinistas. A empresa está contratando novos trabalhadores com salário maior do que os companheiros que já trabalham na área. Ou é incompetência ou uma ação premeditada. E agora, pra piorar, a CSN melhora o salário dos líderes, que merecem, mas não resolve o problema da equiparação salarial. (Boletim 9 de novembro de 03 de dezembro de 2010)

No caso dos trabalhadores da manobra, a desterceirização dificilmente levou à ampliação dos custos, pelo contrário. Em conjunto com novas tecnologias, a desterceirização permitiu a polivalência, o aumento da flexibilidade e a redução de pessoal, ao mesmo tempo em que manteve os salários das terceirizadas, e eliminou as demandas por reconhecimento de vínculo de trabalho de manobreiros em relação à CSN.

63 O entrevistado foi presidente do Sindmetal-SF de 2006 a 2014 e, desde então, ocupa a vice-presidência do sindicato. Entrou na CSN no final dos anos 1970. Trabalhou na usina como eletricista na Coqueria, área de produção de coque para a redução do minério de ferro. 


\section{CONCLUSÃO}

Ao trazer a este texto análises e hipóteses sobre as investidas e a dificuldade de implementar determinados tipos de polivalência na CSN, não pretendemos afirmar que a terceirização impede a multifucionalidade. As mudanças em direção ao acúmulo de funções também se desenvolvem nos quadros das empresas contratadas. Além do acúmulo de diferentes funções na manutenção, em 2004 o Sindmetal-SF denunciou frequentemente o desenvolvimento da dupla função de embalador-manobreiro ${ }^{64}$. No entanto, nas contratadas a polivalência derivava da junção de atividades terceirizadas, não atingindo as atividades de operação da CSN.

Uma das questões frequentemente levantadas pelos pesquisadores consiste em compreender se a polivalência por fusão de postos de trabalho representa um aumento da autonomia e das capacidades no trabalho, tal como propõe o modelo flexível, ou se ela representa apenas acúmulo de trabalho desqualificado. Em um contexto diferente, mas buscando responder à esta questão, Everaere (2012) estabeleceu uma diferenciação entre flexibilidade quantitativa e qualitativa nas empresas: enquanto a primeira caracteriza a contratação de coletivos com contratos instáveis, em geral com baixa qualificação, a segunda representa a contratação de trabalhadores mais qualificados, que gozam de contratos mais estáveis. Há dois tipos de polivalência antinômicas que tem efeitos divergentes para a força de trabalho: a flexibilidade qualitativa implica na expansão das tarefas a partir da recomposição das funções e ocupações, exigindo maior treinamento, qualificação, e investimento das empresas em novas competências; e a flexibilidade quantitativa, baseada na simples rotação de postos de trabalho, que penaliza o trabalhador sem oferecer-lhe qualquer expansão no conteúdo do trabalho ou qualquer avanço em suas qualificações e competências (Everaere, 2012). O trabalhador temporário seria o arquétipo deste tipo de polivalência no estilo "tapa buraco", ou "pau-para-toda-obra" (Everaere, 2012, p.24). Em lugar da autonomia e da competência vinculados à multifuncionalidade sob a égide do Toyotismo, a flexibilidade quantitativa

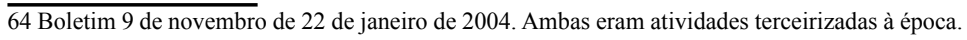


se apresenta a partir das mesmas propriedades do trabalho taylorizado, repetitivo, destituído de conteúdo, ou ainda, de um tipo de organização do trabalho supostamente superado.

Grande parte das entrevistas, bem como das análises sobre a desterceirização apontam a redução de postos de trabalho como parte do processo. Como dissemos anteriormente, não dispomos de informação suficiente para estimar o número de postos suprimidos, no entanto é bastante verossímil a afirmação de que a desterceirização permite um redimensionamento/redução do contingente de funcionários das empresas. Neste trabalho buscamos estabelecer uma relação entre desterceirização, multifuncionalidade e intensificação do trabalho. A prática da desterceirização pode frequentemente gerar uma ilusão numérica: o aumento em termos absolutos dos quadros diretos das empresas pode ter (e frequentemente tem) como reflexo a redução do contingente de trabalhadores de uma área/setor. Não foi outra a conclusão a que chegaram Dias e Oliveira (2012) ao analisar a desterceirização no setor bancário e na siderurgia: ela veio em parte acompanhada pelo desemprego, e pela intensificação do trabalho. Portanto, a desterceirização, contraditoriamente, também permite um enxugamento dos quadros das empresas (Dias e Oliveira, 2012). Se a desterceirização implica na retomada da integração vertical, e no aumento dos efetivos próprios das empresas, elas não são mais tão "gordas" e "inchadas" como na sua versão fordista. Em convergência com parte da bibliografia mais recente da Administração de Empresas acreditamos que a desterceirização reforça a dimensão da plasticidade das fronteiras da firma.

Resta ainda responder à questão proposta no início da seção: a desterceirização seria uma nova estratégia da produção flexível, do pós-fordismo? Consideramos que o problema reside na questão tal como formulada. Em lugar de tentar amarrar as práticas a esquemas fechados e estáticos, nosso objetivo nesta pesquisa foi antes demonstrar que tanto a terceirização quanto a desterceirização podem favorecer ou não a flexibilidade nas empresas, a depender de fatores conjunturais vinculados ao tipo de processo produtivo, à relação entre os efetivos e à regulação vigente. Lomba (2005) critica a binarização utilizada para compreender a organização do trabalho a partir 
de categorias estanques como "Pós-taylorismo" e "Neo-taylorismo". $\mathrm{O}$ autor retoma os trabalhos realizados por Boyer e Freyssenet em indústrias automobilísticas de diferentes países para demonstrar que não há um best way, ou seja, que não existe um modelo único, indiviso e coerente aplicado pelas empresas à produção e organização do trabalho (Boyer e Freyssenet apud Lomba, 2005, p. 73). Pelo contrário, práticas variadas, nem sempre em convergência com fórmulas consagradas de eficiência, podem ser rentáveis em diferentes países, ou dentro de um mesmo país em diferentes empresas. A coexistência de uma variedade de orientações caracteriza o cotidiano das práticas de trabalho e, por isto, o autor enfatiza a necessidade de estudos verticalizados que se proponham a compreender as trajetórias e estratégias desenvolvidas pelas empresas a partir dos desafios específicos com os quais elas se deparam (Lomba, 2005). Em sentido provocativo, nos limitaremos a afirmar que ao aprofundar a separação entre concepção e execução e ao se restringir às atividades-fim das empresas $^{65}$, a terceirização não se mostrava tão flexível. Por outro lado, ao favorecer a polivalência e permitir ajustes conjunturais às empresas, a desterceirização não nega a flexibilidade. Enquanto a terceirização ganhou grande notoriedade, em função mesmo da rapidez com a qual se expandiu, as desterceirizações ainda têm recebido pouca atenção dos pesquisadores, e têm se desenvolvido de maneira geral à margem das críticas, talvez em função do processo parecer um movimento em sintonia com aquilo que desejavam os críticos da terceirização.

\section{REFERÊNCIAS}

BIAVASCHI, M B.; DROPPA, A. A história da súmula 331 do Tribunal Superior do Trabalho: a alteração na forma de compreender a terceirização. Mediações: Londrina, Vol. 16, n 1, p. 124-141, 2011.

CARDOSO, A. M. A década neoliberal e a crise dos sindicatos no Brasil. São Paulo: Boitempo Editorial, 2003.

CARDOSO, L. A; ROMÃO, F. L. "Primeirização": um modelo pósfordista de organização do trabalho na indústria brasileira. In: $X V^{o}$ Congresso Brasileiro de Sociologia (SBS), Curitiba, 2011. 
CARELLI, R. de L. Terceirização e direitos trabalhistas no Brasil. In: DRUCK, G.; FRANCO, T. (Orgs.). A perda da razão social do trabalho: terceirização e precarização. São Paulo: Boitempo, 2007.

CASTELLS, M. A sociedade em rede. Rio de Janeiro: Paz e Terra, 1999.

CHAILlOU, B. Definition et typologie de la sous-traitance. Revue economique, Vol. 28, nº 2, p. 262-285, 1977.

CLASSIFICAÇÃO BRASILEIRA DE OCUPAÇÕES, Ministério do Trabalho e Emprego (MTE), 1982.

CLASSIFICAÇÃO BRASILEIRA DE OCUPAÇÕES, Ministério do Trabalho e Emprego (MTE), 1994.

CLASSIFICAÇÃO BRASILEIRA DE OCUPAÇÕES, Ministério do Trabalho e Emprego (MTE), 2002.

CORIAT, B. Pensar pelo avesso: o modelo japonês de trabalho e organização. Rio de Janeiro: UFRJ/Revan, 1994.

DIAGNÓSTICO DA FORMAÇÃO PROFISSIONAL / RAMO METALÚRGICO. São Paulo: Artchip Editora, 1999.

DIAS, S. de O. M. Do paradigma da terceirização à prática da desterceirização nas empresas. In: OLIVEIRA, R. V. de; SANTANA, M. A. (Orgs.). Trabalho em territórios produtivos reconfigurados no Brasil. João Pessoa: Editora da UFPB, 2013, p. 75-106.

DIAS, S. de O. M. Joint ventures, displacements and collective bargaining: the case of Companhia Siderúrgica Nacional. Sociologia del Lavoro, Vol. 1, p. 82-98, 2018.

DIEESE. Terceirização e precarização das condições de trabalho: Condições de trabalho e remuneração em atividades tipicamente terceirizadas e contratantes. Nota técnica, 172. São Paulo: Dieese, 2017.

DRUCK, G.; FRANCO, T. Terceirização e precarização: o binômio antisocial em indústrias. In: DRUCK, G.; FRANCO, T. (Orgs.) A perda da razão social do trabalho: terceirização e precarização. São Paulo: Boitempo, 2007.

EVERAERE, C. Flebixilité apliquée aux resources humaines. Compatibilités et contradictions. Revue française de gestion. 221 (2), 13-32, 2012.

FARIA, A. de. Terceirização: Um desafio para o movimento sindical. In: MARTINS, H.; RAMALHO, J. R. Terceirização: diversidade e negociação no mundo do trabalho. São Paulo: Editora Hucitec, 1994. 
Desterceirização e flexibilidade: retorno à integração vertical e o impulso à polivalência.

HARVEY, D. A Condição Pós-moderna. São Paulo: Edições Loyola, 1992.

KREIN, D. Tendências recentes nas relações de emprego no Brasil (19902005). 2007. 319 p. Tese (Doutorado em Economia Aplicada), Universidade Estadual de Campinas, Programa de Pós-Graduação em Economia Aplicada, Campinas, 2007.

LEIRIA, J. S. Terceirização. Porto Alegre: Editora Ortiz, 1991.

LOMBA, C. Beyond the debate over 'Post'- vs 'Neo'-Taylorism: the contrasting evolution of industrial working practices. International Sociology, Vol. 20, no 1, p. 71-91, 2005.

MARCELINO, P. R. Trabalhadores terceirizados e luta sindical. $1^{\mathrm{a}}$ ed. Curitiba: Editora Appris, 2013.

NOLLET, J.; PONCE, S. Après l'impatition...la désimpatition? Gestion, 29 (2), p. 57-65, 2004.

NOZOE, N. H.; BIANCHI, A. M.; RONDET, A. C. A. A nova classificação brasileira de ocupações: anotações de uma pesquisa empírica. São Paulo em perspectiva, São Paulo, 17 (3-4), p. 234-246, 2003.

OLIVEIRA, R. G; DIAS, S. de O. M. Novas e velhas práticas do mundo do trabalho: desterceirização e flexibilização das relações de trabalho. Revista Pós Ciências Sociais, São Luis, MA, Vol. 9, n 18, p. 181206, 2012.

OLIVEIRA, R. G. de. Desterceirização" e a intensificação do trabalho: idas e vindas da flexibilidade no setor bancário Estatal. 2009. 142 p. Dissertação (Mestrado em Sociologia e Antropologia), Instituto de Filosofia e Ciências Sociais, Universidade Federal do Rio de Janeiro, Rio de Janeiro, 2009.

PICCININI, V. C.; ALMEIDA, M. L. de; OlIVEIRA, S. R. de. (Org.) Sociologia e administração: relações sociais nas organizações. Rio de Janeiro: Elsevier, 2011.

POCHMANN, M. A superterceirização do trabalho. São Paulo: Ltr, 2008.

RAMALHO, J. R.; RODRIGUES, I. Trabalho, flexibilidade e terceirização: o caso da indústria automotiva. In: DAU, D. M.; RODRIGUES, I. J.; CONCEIÇÃO, J. J. (orgs). Terceirização no Brasil: do discurso da inovação à precarização do trabalho. São Paulo: Annablume, 2009.

SANTANA, R. Práticas de terceirização nas empresas industriais. In: DRUCK, G.; FRANCO, T. (Orgs.). A perda da razão social do trabalho: terceirização e precarização. São Paulo: Boitempo, 2007.

SANTOS, G. M. R. dos; GARROCHO, C. S. Terceirização ou primarização? 
Eis a questão. Anais eletrônicos do $28^{\circ}$ Congresso Brasileiro e $5^{\circ}$ mundial de manutenção e gestão de ativos, 2013.

WATANABE, M; BOUÇAS, C. Fiscalização e Busca de eficiência tiram força da terceirização. Valor Econômico: São Paulo, 25/08/2008.

\section{Sites consultados:}

h t t p : // w w w. sindmetalsf.org.br/sind_boletins. asp?menu $=$ comunicacao\&submenu=boletins

http://www.mtecbo.gov.br/cbosite/pages/pesquisas/BuscaPorTitulo.jsf

https://www.trt1.jus.br/consulta-acordao

http://dataviva.info/pt/ 